\title{
THE IMPACT OF ENFORCEMENT OF CORRUPTION LAW BY THE CORRUPTION ERADICATION COMMISSION AFTER THE RATIFICATION OF THE LATEST KPK LAW
}

\author{
Ayu Putriyana*, Nur Rochaeti* \\ *Magister Ilmu Hukum, Universitas Diponegoro, Semarang, Jawa Tengah \\ Correspondence email: avrivana.24@gmail.com \\ Paper received on: 27-04-2021; Revised on: 19-08-2021; Approved to be published on: 03-09-2021 \\ DOI: http://dx.doi.org/10.30641/dejure.2021.V21.299-310
}

\begin{abstract}
2019 was a year full of turmoil for the KPK (Corruption Eradication Commission) due to the revision of the KPK Law after 17 years of the KPK Law being in effect. Despite many rejections, the latest KPK Law was still passed in September 2019 so that it became Indonesia's positive law. Therefore, the statements of the problem in this research are: what is the cause of the KPK Law revision and what is the impact of law enforcement on corruption by the KPK after the ratification of the latest KPK Law. The purpose of this research is to find out the reasons for the revision of the KPK Law and the impact of the implementation of the latest KPK Law. The method used in this research is a normative juridical method with a descriptive qualitative approach. The results of the research indicate that there are several weaknesses of the previous KPK Law which have an impact on the performance of the KPK so that it has not provided maximum results. In fact, regarding the impact of the enactment of the latest KPK Law, it has not given positive results so that it affects the stability of law enforcement for corruption. Therefore, there needs to be a good adaptation for the KPK and all related parties so that the latest KPK Law can run well.
\end{abstract}

Keywords: impact; corruption; KPK

\section{INTRODUCTION}

Since the reformation, the condition of law enforcement in Indonesia, especially against corruption, has been in a state of legal emergency. Corruption is no longer an extraordinary crime, but has led to crime against humanity. ${ }^{1}$ The practice of corruption seems to have become an "acute disease" in Indonesia. In fact, every year many corruptors are caught by law enforcement officers. However, the news about the arrested corruptors did not discourage other corruptors at all. In fact, the practice of corruption is increasingly massive in Indonesia. ${ }^{2}$ This makes corruption considered an extraordinary crime or crime against humanity because corruption is carried out in a systematic, widespread way and there are many negative impacts caused by corruption. ${ }^{3}$

Moh Hatta, KPK Dan Sistem Peradilan Pidana (Yogyakarta: Liberty Yogyakarta, 2014), 37.

2 B Daya, "Memperkuat KPK, Memberantas Korupsi," Lex Librum: Jurnal Ilmu Hukum 5 (2019): 875-886.

3 Evi Hartanti, Tindak Pidana Korupsi, 2nd ed. (Jakarta: Sinar Grafika, 2012), 1.
Corruption itself undeniably has strong implications for the sustainability of a country. This is supported in the statement of the Preamble of the United Nations Convention Against Corruption (UNCAC), that "Corruption is an insidious plague that has a wide range of corrosive effects on societies. It undermines democracy and the rule of law, leads to violations of human rights, distorts markets, erodes the quality of life and allows organized crime, terrorism and other threats to human security to flourish". So, handling corruption cases is not only through conventional ways, but also requires an extra and specific approach. ${ }^{4}$

Based on the journey of law enforcement against corruption in Indonesia, the government has made various efforts to strengthen the eradication of corruption in this country. However, it must be acknowledged that the eradication of corruption has not been carried out optimally. Government

\footnotetext{
4 Artidjo Alkostar, Korupsi Sebagai Extra Ordinary Crime (Training Pengarusutamaan Pendekatan Hak Asasi Manusia Dalam Pemberantasan Korupsi di Indonesia Bagi Hakim Seluruh Indonesia, 2013), 1.
} 
institutions that handle corruption cases have not functioned effectively and efficiently in eradicating corruption. ${ }^{5}$ Indonesia's seriousness in eradicating corruption can be seen from national policies, which are outlined in several regulations and the establishment of special institutions in Indonesia which are tasked with focusing on preventing and prosecuting corruption cases, such as the Commission Four, the Commission for Supervision of State Officials Wealth (KPKPN), the Joint Team for the Eradication of Corruption (TGPTPK) and the Corruption Eradication Commission (KPK).

The KPK is one of the 'biological children' of reformation, which was established due to public anxiety about the weak performance of law enforcement officers in Indonesia in dealing with and eradicating rampant corruption. ${ }^{6}$ This institution was established in 2002 through Law Number 30 Year 2002 concerning the Corruption Eradication Commission. However, the KPK has only been functional and effective since $2003 .{ }^{7}$ The KPK began to show its capability as a special anti-corruption agency in 2004 by bringing Abdullah Puteh, the former Governor of Nanggroe Aceh Darussalam as a suspect in corruption in the procurement of helicopters worth IDR 12.5 billion. Then, in 2005, a surprise emerged from the implementation of the role of the KPK, namely the successful disclosure of the case of Mulyana Wira Kusuma, a member of the General Election Commission (KPU) who tried to bribe one of the BPK (Supreme Audit Agency) auditors. ${ }^{8}$

The presence of the KPK is crucial in efforts to accelerate and effectively implement the eradication and prevention of corruption in Indonesia. The corruption eradication system planned and implemented by the KPK from 2002 to early 2019 was quite effective, especially with the existence of special authority through Sting Operation (OTT) which was carried out since 2013. This affected the increase in the number

5 Denny Indrayana, Jangan Bunuh KPK (Malang: Intrans Publishing, 2016). 192.

6 Nehru dan Adam Setiawan Asyikin, "Kedudukan KPK Dalam Sistem Ketatanegaraan Pasca Diterbitkannya Revisi Undang-Undang KPK," Justitia Jurnal Hukum Volume 4, no. 1 (2020): 126-147.

7 Ibid.

8 Totok Sugiarto, "Peranan KPK Dalam Pemberantasan Tindak Pidana Korupsi Di Indonesia," Jurnal Cakrawala Hukum 18, no. 1 (2013): 188-196. of cases that could be handled by the KPK. In addition, with the OTT, it is able to show increased concern of the community regarding existing corruption cases. This is because without public awareness and reports, it is unlikely that OTT will be carried out.

To increase the number of cases that can be handled by the KPK, special authority such as OTT is needed by the KPK as a special institution that handles corruption cases. The KPK needs to be given special authority to facilitate their performance. However, in reality, the implementation of the duties, functions, and authority of the KPK encountered many obstacles. The KPK has been repeatedly "weakened" in various ways by those whose positions are threatened by the existence of the KPK. The form of weakening that has occurred is like in 2018 where the House of Representatives' questionnaire committee raised a discourse so that the KPK was not given a budget, the discourse on the dissolution of the KPK and there was also the issue of the age of the KPK being only 12 years old. However, one of the most volatile forms of weakening within the KPK was the enactment of Law Number 19 Year 2019 concerning the Second Amendment to Law Number 30 Year 2002 concerning the Corruption Eradication Commission.

The latest KPK Law has reaped the pros and cons since the beginning of the process of implementing the amendments to the KPK Law which seemed forced. Through the House of Representatives plenary meeting, all members of the House of Representatives agreed unanimously to revise the KPK Law as an initiative of the House of Representatives in 2019. The decision-making process was so short that it only took five minutes without any interruptions of rejection from other members of the House of Representatives. In fact, the revision of the KPK Law was not included in the list of Priority Prolegnas (National Legislative Program). However, it is still approved for a revision of the KPK Law. ${ }^{9}$

Articlesthathavereceivedmoreattentionfrom the latest KPK Law include Article 3 concerning the KPK as an executive state institution, Article 37A concerning the Supervisory Board (Dewas), Article 12B concerning wiretapping which

\footnotetext{
9 Adam Setiawan, "KPK Di Ambang Kehancuran," Kaltim Prokal.
} 
must with the approval of the Dewas, Article 24 paragraph (2) concerning the status of KPK employees as Civil Servant and the abolition of several provisions in the previous KPK Law, such as the abolition of the Advisory Board, the criteria for corruption cases in the phrase "getting public attention" and the status of investigators or public prosecutors on the KPK leader.

The amendment to the KPK Law had sparked off demonstrations from various parties due to differences of opinion regarding the timing and substance of the revision of the KPK Law. ${ }^{10}$ These articles are considered not to support the KPK to move forward and can hamper the performance of the KPK. The government did not heed criticism from various parties on the revision of the KPK Law as on September 17, 2019, the old KPK Law was officially replaced. ${ }^{11}$ Over time, the latest KPK Law has been in effect for approximately 2 years and an evaluation can be carried out on whether the implementation of the Law has a good impact or not, as predicted by various parties who are against the latest KPK Law, especially the articles that are indeed has become problematic and considered irrelevant.

Based on the description of the background, the following problems are formulated: First, what causes Law Number 30 Year 2002 concerning the Corruption Eradication Commission to be revised? Second, what is the impact of law enforcement on corruption by the KPK after the ratification of the latest KPK Law?

\section{RESEARCH METHOD}

This research is normative juridical research related to the latest KPK Law and the impact of its implementation as a positive law in Indonesia. The approach used in this research is descriptive qualitative research by analyzing secondary data to obtain an overview of the causes and effects of the latest KPK Law. Meanwhile, the legal materials used are primary legal materials in the form of laws and regulations, such as Law Number 8 Year 1981 concerning the Criminal Procedure Law (KUHAP), Law Number 30 Year 2002 concerning the Corruption Eradication Commission,

10 Ibid.

" Madaskolay Viktoris Dahoklory and Muh Isra Bil Ali, "Menyoal Urgensi Dan Prosedur Pembentukan Revisi Undang-Undang Komisi Pemberantasan Korupsi," Perspektif 25, no. 2 (2020): 120.
Law Number 16 Year 2004 concerning the Prosecutor's Office of the Republic of Indonesia and Law Number 19 Year 2019 concerning the Second Amendment to Law Number 30 Year 2002 concerning the Corruption Eradication Commission. Secondary legal materials are books and journals about the KPK, corruption and the criminal justice system.

\section{DISCUSSION AND ANALYSIS}

\section{A. The causes of Law Number 30 Year 2002 concerning the Corruption Eradication Commission must be revised}

1. The coordination among the KPK, the Police and the Prosecutor's Office is not running smoothly

Eradication of corruption is a series of actions to prevent and eradicate corruption through coordination, supervision, monitoring, preliminary investigation, full investigation, prosecution, and examination in court proceedings with public participation based on the applicable laws and regulations. In Indonesia, the institutions that have the right to handle corruption consist of 3 (three) institutions, namely the Police, the Prosecutor's Office and the KPK. The three institutions have their respective duties and responsibilities to investigate corruption.

The rules for enforcing the law on corruption are different among these institutions. The police refer to Law Number 8 Year 1981 concerning the Criminal Procedure Law (KUHAP), the Indonesian police officers are to act as case investigators. Therefore, the police are authorized to be investigators for every criminal act, including corruption. The authority of the Prosecutor's Office to conduct investigations is stated in Law Number 16 Year 2004 concerning the Prosecutor's Office of the Republic of Indonesia. Based on Article 30 of Prosecutor's Office Law, the Prosecutor's Office has the authority to conduct investigations into certain criminal acts based on the law. As for the KPK, its authority is given by Law Number 30 Year 2002 concerning the Corruption Eradication Commission in Article 6 of the Law. ${ }^{12}$ In Article 6 letter a of the KPK Law, the KPK has the task of coordinating with authorized institutions

${ }^{2}$ Junaidi Abdullah, "Tugas Dan Wewenang LembagaLembaga Penanganan Tindak Pidana Korupsi Di Indonesia," Yudisia 5, no. 1 (2014): 102-122. 
such as the Police, the Prosecutor's Office, the Supreme Audit Agency (BPK), the Finance and Development Supervision Body (BPKP), and the Commission for Supervision of State Officials Wealth (KPKPN). In addition, the coordination and supervision of the KPK are also contained in Article 42 and Article 50 of the KPK Law.

The form of coordination and supervision carried out by the KPK with other authorized institutions such as the making of a Joint Agreement between the Prosecutor's Office. the Police, and the Corruption Eradication Commission Number KEP-049/A/J.A/03/2012. B/23/III/2012 and SPJ-39/01/03/2012 Year 2012 concerning Optimizing the Eradication of Corruption ("Joint Agreement") with the aim of developing cooperation between the Prosecutor's Office, the Police, and the KPK (hereinafter referred to as "PARTIES") in optimally eradicating corruption. The cooperation to prevent corruption is carried out through the design of activities of coordination and supervision of the eradication of corruption in the context of increasing the institutional accountability and integrity of the PARTIES in accordance with the provisions of laws and regulations.

However, several times the relationship between the KPK and the Prosecutor's Office, especially with the Police, was marked by tensions when the KPK investigated allegations of corruption involving the leader of the Police and members of the Prosecutor's Office. The form of tension between the KPK and the Police, for example, occurred as in the Cicak VS Buaya (House Lizard VS Crocodile) case volume 1 in 2009 where the term originated from an interview with Tempo Magazine with the then Head of the Criminal Investigation Division (Kabareskrim), Susno Duadji. Then, not long after the horrendous interview because of the phenomenal sentence about Cicak VS Buaya, Susno Duadji was named a suspect. The determination of Susno Duadji as a suspect began with a preliminary investigation (tapping) carried out by the KPK. Susno Duadji was suspected of receiving gratuity from a Bank Century customer, Boedi Sampoerna. The gratuity was given allegedly because Susno Duadji managed to "force" Bank Century to disburse customer funds before the bank was closed. In addition, the two main cases that dragged Susno Duadji's involvement were the security corruption case in the West Java Governor election and the case of PT Salmah Arowana Lestari (SAL) owned by Anggodo Widjojo.

Then, tensions between the KPK and the Indonesian National Police (Polri) continued in the case of Cicak VS Buaya volume 2 in 2012 after the KPK named the former Head of the Police Traffic Corps Inspector General Djoko Susilo as a suspect in a corruption case in the Driving License test simulator project. In fact, previously, the National Police Headquarters had stated that, after conducting an internal investigation, no elements of corruption were found in the project, including the one involving Djoko Susilo. When the KPK announced Inspector General Djoko Susilo as a suspect, a series of irregularities occurred from the Police. Suddenly, they announced that they were actually investigating the same corruption case.

In 2015, there was another commotion between the KPK and the Police which later became the Cicak VS Buaya case volume 3. This started when the KPK named the candidate for the National Police Chief, Commissioner General Budi Gunawan, a suspect in a corruption case, and there were even indications of money laundering. Then, as if it was a counterattack, Polri named KPK Deputy Chairman Bambang Widjojanto as a suspect because he was involved in providing false information in a trial held by the Constitutional Court regarding the 2010 Local Election dispute in West Kotawaringin. At that time, the relationship between the KPK and the Police was heated again. The conflict of the KPK vs Police was getting hotter and wider horizontally. ${ }^{13}$

Not only with the Police, there is a lack of harmony between the KPK and the Prosecutor's Office, although the frequency is minimum. This can be seen when a suspect involving elements of the Prosecutor's Office is considered unavoidable from a conflict of interest because the elements of the KPK consist of the Prosecutor's Office involving individuals from both institutions. A feud had occurred between the KPK and the Prosecutor's Office in the corruption case where the defendant was Prosecutor Pinangki Sirna Malasari. Allegations that this case is progressing slowly and involving other parties or officials of the Prosecutor's Office and that there is a

13 Asep A. Sahid, "Konflik KPK VS POLRI Jilid III: Kontestasi Kuasa Dalam Penegakan Hukum Di Indonesia," Asy-Syari'ah 17, no. 2 (2015): 140. 
conflict of interest in the Adhyaksa institution are unavoidable. The public is also skeptical that this case can be resolved fairly. This raises the option for the KPK to take over this case from the Prosecutor Office. The KPK has also made a move by investigating any related parties mentioned in the Prosecutor Pinangki case. However, the Attorney General's Office confirmed that the Prosecutor Pinangki case would not be handed over to the KPK.

Based on the description above, it can be seen that the KPK, the Police and the Prosecutor's Office as institutions that should coordinate well in uncovering corruption cases end up arguing and not showing harmony or integration in solving corruption problems in this country. In fact, the division of authority to take action against corruption cases between the KPK, Polri and the Prosecutor's Office has been clearly regulated. This is of course contrary to the concept of Integrated Criminal Justice System which is being pursued in Indonesia.

Romli Atmasasmita argues that the Integrated Criminal Justice System as a law enforcement contains legal aspects that focus on the operationalization of laws and regulations in an effort to tackle crime and aim to achieve legal certainty. On the other hand, if the definition of the Criminal Justice System is seen as part of the implementation of social defense related to the goal of realizing community welfare, then the Criminal Justice System contains social aspects that emphasize functions. ${ }^{14}$

Until now, the implementation of the Criminal Justice System has not been able to show maximum results because the parties are structurally not independent and positioned under executive power (government) so that the implementation of criminal law enforcement is not optimal due to executive intervention. The Criminal Justice System has not yet been realized systemically too. The Criminal Justice System tends to be partial and fragmentary, giving rise to rivalry between subsystems which leads to non-optimal performance of the Criminal Justice System, such as the case of rivalry between the KPK, Polri and the Prosecutor's Office which tends to be destructive.

14 Romli Atmasasmita, Sistem Peradilan Pidana Kontemporer (Jakarta: Kencana Prenada Media Group, 2010). 9.

\section{KPK's performance is considered less than optimal and has not provided maximum results}

The results of the investigation by the House of Representatives' Questionnaire Committee showed that the performance of the KPK as an institution that specifically handles corruption cases has not been maximized even though the problem of eradicating corruption is not the task of the KPK alone. This can be seen from the Corruption Perception Index (CPI) of Indonesia which has not improved when compared to countries that geographically have a large territory and demographically have a relatively large population in the world like Indonesia. Indonesia's CPI is still below and even far behind when compared to countries in Asia, such as Japan, South Korea, and Saudi Arabia. ${ }^{15}$

Transparency International Indonesia (TII) released Indonesia's 2020 CPI on January 28, 2021. TII Research Manager Wawan Suyatmiko said that Indonesia's current CPI score is 37 on a scale of $0-100$. As for the score 0 to declare a very corrupt country and a score of 100 to declare a very clean country and Indonesia's score in 2020 was 3 points down from 2019. Wawan Suyatmiko also said that the decline in Indonesia's CPI also brought Indonesia's position down to 102. Based on 180 countries that had their CPI assessed in the previous year, Indonesia was in 85 th position. Eradication of corruption has become a routine movement of all countries. However, corruption remains rampant and gradually this practice becomes a culture. ${ }^{16}$

It is undeniable that there are several problems that cause the KPK's performance to be less than optimal in carrying out its duties and authority. This is because in the old KPK Law there were no firm and clear regulations regarding several matters such as regulations of confiscated assets, asset recovery, management of investigators, the overlapping authority with law enforcement institutions, Investigation Termination Order (SP3) and the absence of supervisory agency capable of supervising the implementation of the duties and authority of the KPK. These weaknesses are

15 Fathiyah Wardah, "Panitia Angket DPR Simpulkan Kinerja KPK Belum Maksimal,” VOA Indonesia.

16 Indriyanto Seno Adji, Korupsi Kebijakan Aparatur Negara Dan Hukum Pidana ((Jakarta: Diadit Media, 2009). 373 . 
contained in the old KPK Law, so revising it is a natural thing. However, the revision must support the KPK in carrying out its duties and authority in order to obtain maximum results.

Indonesia has high hopes for the KPK to handle corruption cases. Moreover, this is because the KPK is given special rights to investigate corruption cases, such as recognition as an independent institution, OTT actions, wiretapping and recording conversations. Although it cannot be denied that the KPK also has good achievements in its performance. The KPK is considered capable of uncovering extraordinary corruption cases committed by state officials, such as Regents, Governors, and Ministers. The KPK has also spearheaded demands for the revocation of political rights for perpetrators of corruption, such as the defendants Anas Urbaningrum, Luthfi Hasan Ishaaq, Akil Mochtar, and Ratu Atut Chosiyah.

\section{The institutional status of the KPK which} is considered to have unclear qualifications

The legal politics of establishing anticorruption institution in Indonesia began with a constitutional mandate as stated in the MPR Decree No. XI/MPR/1998 concerning State Officials that are Clean and Free from Corruption, Collusion, and Nepotism. On the basis of this mandate, the Government followed up on the establishment of Law Number 28 Year 1999 concerning State Officials that are Clean and Free from Corruption, Collusion and Nepotism and Law Number 31 Year 1999 concerning Eradication of Corruption which mandated the establishment of the KPK. ${ }^{17}$ Then, the official position of the KPK is contained in Law Number 30 Year 2002. The KPK is not a state institution, but the KPK is an independent commission whose duties are related to the Supreme Audit Agency (BPK), especially in terms of managing the country. ${ }^{18}$ In the context of institutional formation, the KPK is not meant to take over the task of eradicating corruption from existing institutions. The explanation of the law states that the KPK is a trigger mechanism which

\footnotetext{
Ria Casmi Arrsa, "Urgensi Membentuk KPK Di Daerah," INTEGRITAS Jurnal Anti Korupsi 2, no. 1 (2016): 215-234.

18 Achmad Badjuri, "Peranan Komisi Pemberantasan Korupsi (KPK) Sebagai Lembaga Anti Korupsi Di Indonesia," Jurnal Bisnis dan Ekonomi (JBE), 18, no. 1 (2011): 84-96.
}

means to encourage or as a stimulus so that efforts to eradicate corruption from existing institutions become more effective and efficient. ${ }^{19}$

In carrying out its duties and functions, the KPK has encountered many obstacles, such as criticism from various parties regarding indications of cherry picking in dealing with corruption cases and application for judicial review of Law Number 30 Year 2002. In addition, there are many opinions from the public or the opinions of legal experts regarding the status of the position of the KPK, including the polemic of what state institution does the KPK belong to and whether the KPK is part of the executive or judiciary institutions. The debate about the identity of the KPK as part of the executive institutions or as a separate state institution has indeed surfaced and is often a topic of discussion. This debate took place when the KPK's Select Committee for Questionnaire appeared until the debate entered the 'legal considerations' room of the judges of the Constitutional Court. Indeed, there were two views. The first is to assume that the KPK is part of the executive institution with the assumption that based on the practice in several countries that have institutions similar to the KPK, the institution that carries out the functions of investigation and prosecution can be categorized as part of executive institution. The second is to state that the KPK is an independent state institution. The KPK identity crisis was caused by a discrepancy between what is written in the regulations and the authority given to the KPK in the existing reality.

Article 3 of the previous KPK Law has stated that "The Corruption Eradication Commission is a state institution which in carrying out its duties and authority is independent and free from the influence of any power." However, it seems that this is not enough to give satisfaction until finally the jurisprudence of the Constitutional Court's decisions, namely Decisions Number 012-016019/PUU-IV/2006, 19/PUU-V/2007, 37-39/PUUVIII/2010, and Number 5/PUU-IX/2011 confirms that the KPK is an independent institution that is not within the realm of the executive, legislative, and judicial. The four decisions were also mentioned

\footnotetext{
19 Ria Casmi Arrsa, "Rekonstruksi Politik Hukum Pemberantasan Korupsi Melalui Strategi Penguatan Penyidik Dan Penuntut Umum Independen KPK," Jurnal Rechts Vinding: Media Pembinaan Hukum Nasional 3, no. 3 (2014):381.
} 
by four judges of the Constitutional Court who expressed dissenting opinions or different opinions in the hearing of decisions Number 36/ PUU-XV/2017 and 40/PUU-XV/2017. ${ }^{20}$ The Constitutional Court examined the position and function of the KPK in the governance system, both through the KPK Law, the Corruption Law and the MD3 Law from 2003 to 2018. From several decisions, there are implications and impacts of the Constitutional Court's decision in strengthening the authority and function of the KPK in the governance system. ${ }^{21}$

From the beginning, the idea of establishing the KPK was as a trigger mechanism so that corruption eradication efforts run effectively and efficiently. However, along the way, there are different demands against the KPK that are not in accordance with the original idea of the KPK establishment. The old KPK Law is indeed allowed to be revised because changes are a natural thing. However, the revision should have supported the KPK in handling corruption cases in the future.

\section{B. The impact of law enforcement on corruption by the KPK after the ratification of the latest KPK Law}

\section{Significant reduction in the number of prosecutions of corruption cases}

The latest KPK Law has been controversial since the beginning of the discussion. The revision not only affects the independence of the KPK because it positions the KPK under the executive power, but also affects the internal mechanism for dealing with corruption at the KPK. Reporting from CNN Indonesia-- ICW noted a decrease in the number of prosecutions of corruption cases handled by the KPK in the first semester of 2020 when compared to the same period in $2019 .{ }^{22}$ The ICW's records were based on the handling of corruption cases that had entered the preliminary investigation stage and there are already people who had been named a suspect.

The disappointing part is that when

2o Allan Fatchan Gani Wardhana, "KPK Bukan Eksekutif," PSHK UII.

${ }^{21}$ O V Agustine, E M Sinaga, and R Yulistyaputri, "Politik Hukum Penguatan Kewenangan Komisi Pemberantasan Korupsi Dalam Sistem Ketatanegaraan," Konstitusi 16, no. 2 (2019): 314-338.

${ }_{22}$ Andry Novellno, "ICW: Penindakan Korupsi KPK Terjun Bebas 6 Bulan Terakhir," CNN Indonesia. we compare the number of prosecutions of corruption cases in the first semester of 2019 and the first semester of 2020 , it can be seen that the performance of the KPK has declined. The performance of the KPK in the first semester of 2020 was very poor in the context of prosecution. This was conveyed by ICW researcher Wana Alamsyah in a virtual discussion titled "Trends in Prosecution of Corruption Cases in 2020" on September 29, 2020. Based on the data presented by Wana, from the first semester of 2016 to 2019, the KPK was considered capable of handling an average of 20 corruption cases. If made in more detail, in 2016, there were 18 cases, in 2017 there were 21 cases, in 2018 there were 30 cases and in 2019 there were 28 cases. However, in the first semester of 2020, the KPK was only able to handle 6 cases. The handling of these 6 cases is certainly far from the target contained in the 2020 KPK's Budget Implementation List (DIPA), which has a target of 120 cases. If calculated, the handling of the 6 cases means that the KPK is only able to realize $5 \%$ of cases.

There are several things that are suspected to be the cause of the decline in the number of prosecutions of corruption cases by the KPK. First, namely the emergence of the Covid-19 outbreak which directly or indirectly affects the performance of the KPK and hinders the movement of the institutions. This is because it requires adjustments related to the outbreak where Indonesia is still in a position to fight the Covid-19 outbreak. Second, this is of course related to the latest KPK Law which is considered to increasingly make the KPK's work difficult.

Then, the loss of the KPK's authority at the investigation and prosecution stages where there is Article 12 paragraph (2) of the latest KPK Law which states the following:

In carrying out investigation tasks, the Corruption Eradication Commission has the authority to:

a. Order the relevant institutions to prohibit someone from traveling abroad.

b. Request information from banks or other financial institutions regarding the financial condition of the suspect or defendant being investigated.

c. Order banks or other financial institutions to block accounts suspected of being the 
result of corruption belonging to the suspect, defendant, or other related parties.

d. Temporarily suspend a financial transaction, trade transaction, and other agreement or temporarily revoke permits, licenses and concessions carried out or owned by a suspect who is suspected based on sufficient preliminary evidence to be related to the corruption case being investigated.

e. Request assistance from Interpol Indonesia or other state law enforcement institutions to conduct searches, arrests, and confiscate evidence abroad.

f. Request assistance from the Police or other relevant institutions to make arrests, detentions, searches, and confiscations in a corruption case being handled.

This change has an unfavorable impact on law enforcement by the KPK. In the previous KPK Law, with the KPK's broad authority at the level of investigation to prosecution, it was proven to facilitate and maximize the work of the KPK in terms of collecting evidence which will eventually streamline the process of handling the cases and proving the defendant's guilt in court. It seems that the parties who are against corruption eradication in the country are already very angry with the existence of the KPK so that its existence must be eradicated immediately. ${ }^{23}$

\section{The decline in the number of OTT prosecutions}

Corruption is an immoral act that violates the norms and values of goodness. ${ }^{24}$ Today, corruption has plagued Indonesia to the point that some say that corruption has entrenched some of its public officials. ${ }^{25}$ Moreover, the KPK as an anti-corruption agency which is currently operating based on the latest law, is considered to be a bit limping in handling corruption cases in this country. In fact, since its establishment, the KPK has become a trigger mechanism for an independent institution

\footnotetext{
${ }^{23}$ Labib Muttaqin and Edy Susanto, "Mengkaji Serangan Balik Koruptor Terhadap KPK Dan Strategi Menghadapinya," Jurnal Integritas 4, no. 1 (2018): 101144.

24 Muhammad Nurdin, Pendidikan Anti Korupsi (Yogyakarta: Ar Ruzz Media, 2014). 7.

${ }_{25}$ Zainal Arifin Mochtar, Lembaga Negara Independen: Dinamika Perkembangan Dan Urgensi Penataannya Kembali Pasca-Amandemen Konstitusi (Jakarta: Rajawali Pers, 2017). 82.
}

that can overcome public skepticism about the weakness of law enforcement. The KPK also has legal facilities and infrastructure with an extraordinary level of authority that is different from other institutions. ${ }^{26}$

The current assessment of the implementation of the latest KPK Law can be judged to be too fast if it concludes that corruption law enforcement is lame after the enactment of the latest KPK Law. Based on the number of OTTs carried out after the enactment of the latest KPK Law, throughout 2020 , the KPK only managed to carry out 7 OTTs. This is very minimal when compared to 2018 where there were 30 OTTs and in 2019 where there were 21 OTTs.

One of the reasons the KPK was not as active as the previous year in conducting OTT was because the KPK was lame. The lameness referred to here is a condition when the KPK does not have a balance to enforce the law regarding the handling of corruption optimally. This is because the performance of KPK investigators has slowed down due to the presence of other parties within the KPK. This is especially because of the changes to the wiretapping bureaucracy in Article 12B which is quite time-consuming. Many people think that the KPK Supervisory Board (Dewas) can actually weaken the KPK. The public's perception of this Dewas can be right or it can be very wrong. ${ }^{27}$

After the OTT of Wahyu Setiawan who was named a suspect in the alleged bribery case related to the stipulation of the elected members of the House of Representatives for the 20192024 period, problems arose when the search and confiscation plan in question had not yet received the approval from the Dewas. In fact, on the other hand, the KPK wanted to immediately conduct search and confiscation to avoid the act of eliminating evidence that might be carried out by unscrupulous persons. This is because this problem cannot be expressed clearly and comprehensively. As a result of not getting permission from the Dewas, there were several KPK investigators who continued to go forward to conduct search and confiscation at the PDI Perjuangan Headquarters. As a result, the actions of the KPK investigators

\footnotetext{
${ }_{26}$ Indriyanto Seno Adji, KPK Dan Penegakan Hukum (Jakarta: Diadit Media, 2015). 1.

27 Dalinama Telaumbanua, "Restriktif Status Dewan Pengawas KPK," Jurnal Education and development Volume 8, no. 1 (2020): 258-261.
} 
actually received a reply in the form of a report from the PDI Perjuangan management to the Dewas for being considered not complying with the authority of the Dewas..$^{28}$ Syamsudin Haris, one of the Dewas members, denied that the Dewas did not immediately give permission. According to him, Dewas had been waiting since January 9, but the KPK had only submitted a permit on January 10 at night. ${ }^{29}$

Apart from the issue regarding the permit above, the condition that occurred between the KPK investigators and the Dewas focused on the new licensing bureaucracy that previously did not exist. However, with the new KPK Law, the procedure has changed so that the KPK has problems when carrying out executions. This is due to the enactment of the latest KPK Law which gives authority to the Dewas which is included in the realm of pro justitia. Ideally, pro justitia is carried out only by law enforcement officers and not by the Dewas. According to the law, the Dewas has task to grant permission or not grant permission for wiretapping, searches, and/or confiscations.

The latest procedure has the effect of reducing the number of OTT carried out by the KPK. Arresting big-time corruptors to carry out OTT is already difficult because of allegations of impunity. The latest KPK Law is considered by the pros to be a rule to prevent the arbitrariness of the KPK. Turns out, the reality is wrong. In practice, this law does not clearly protect who and what interests. As information circulated widely, the KPK investigators tried to arrest Hasto to the College of Police Science. The investigators were allegedly arrested by a group of police and even forced to do a urine test, as if they were suspected of narcotics crime. This shows that investigators have big obstacles in investigating corruption, especially if they want to carry out OTT and arrest extraordinary corruptors like in previous years.

28 Novalita Sidabutar Arman Tjoneng, Christin Septina Basani, "Menguji Kewenangan Dewan Pengawas Komisi Pemberantasan Korupsi Dalam Pemberian Izin Penggeledahan Sebagai Tindakan Merintangi Proses Penyidikan (Obstruction of Justice)," Jurnal Esensi Hukum 2, no. 2 (2020): 48-61.

29 Korneles Materay, "UU KPK Terbukti Menghambat Kinerja Pemberantasan Korupsi Oleh,” Hukum Online.

\section{Many KPK employees have resigned}

The role of the KPK has so far made the KPK the prima donna institution in society because it is considered capable of resolving corruption cases in Indonesia. This is supported by various authority possessed by the KPK that are not possessed by other law enforcement agencies. On the other hand, the various authority possessed by the KPK are considered as weapons of the KPK which are quite powerful in uncovering various corruption cases in Indonesia. ${ }^{30}$ In addition, the success of the KPK in uncovering corruption cases is also supported by Human Resources (HR) who are professional and have integrity in accordance with their fields. However, it turns out that the HR, who has been carrying out the mandate at the KPK for years, chose to resign after the latest KPK Law was passed.

The resignation of the KPK employees after the ratification of the latest KPK Law was allegedly due to a new rule in Article 24 paragraph (2) which reads: "Employees of the Corruption Eradication Commission are members of the professional corps of civil servants of the Republic of Indonesia in accordance with the provisions of the laws and regulations". This change in the status of the KPK employees is certainly not in line with the KPK which is called an independent institution. In addition, the qualification of the status of the KPK to become an executive state institution in Article 3 of the latest KPK Law also adds to a series of problems in the internal staff of the KPK.

Throughout 2020, 38 KPK employees have resigned. One of the KPK employees who chose to leave the KPK was KPK spokesman Febri Diansyah who stated that he resigned because he could no longer stand the condition at the anticorruption institution. Febri Diansyah felt that the KPK has undergone changes after the ratification of the latest KPK Law. The space to contribute to the eradication of corruption narrowed after the revision, so he chose to resign. In fact, the KPK employees are seen as assets that are the strengths of the KPK.

In addition to Febri Diansyah, there is also a senior KPK employee who is also an Advisor to the KPK Employee Forum (WP), Nanang Farid Syam, who also officially resigned. Nanang Farid

3o Arman Tjoneng, Christin Septina Basani , Op Cit, 77. 
Syam left the KPK after 15 years of serving at the KPK and contributing to the progress of the KPK. Most recently he served as the Directorate of Inter-Commission and Institutional Network Development (PJKAKI). One of the reasons he chose to resign from the KPK was due to the changing condition of the KPK after the enactment of the latest KPK Law. In fact, the new KPK Law regulates that KPK employees must be part of the ASN (Civil Servant). The number of KPK employees who chose to resign shows one of the effects of the changes to the KPK Law. ${ }^{31}$

\section{The declining level of public trust in the KPK}

The year 2002 as the year of the establishment of the KPK was the answer to the public's anxiety and dissatisfaction with the institutions that already existed to deal with corruption. The KPK is a state practice requirement that continues to move following the dynamics of changing times and societal problems. However, after seventeen years of existence, namely in the middle of 2019 there was a change to the KPK Law, which gave rise to various pros and cons among the public. Therefore, there is a problem that makes people think that this new law is not in accordance with the original purpose of the KPK.

After the ratification of the latest KPK Law on September 17, 2019, this means that the law has been implemented in Indonesia for almost 2 years. There are several impacts that can be seen from the recent KPK Law, namely the decline in the level of public trust in this anti-corruption institution. Reporting from CNN Indonesia, in February 2020, the Indo Barometer Survey showed that there was a decline in the level of public trust in the KPK, although the number of public trust in the KPK is still relatively high at $81.8 \%$. With this figure, the KPK only managed to occupy the fourth position under the TNI, the President and Religious Organizations. In fact, in every survey conducted, the institution currently led by Firli Bahuri was always in the top three positions. ${ }^{32}$

Entering July 2020, it turns out that the level of public trust in the KPK has decreased to $74.3 \%$. The Indonesia Corruption Watch (ICW) stated

\footnotetext{
31 Tsarina Maharani, "Ramai-Ramai Mundur Dari KPK, Ada Apa?," Nasional Kompas.

32 "Kepercayaan Publik Ke KPK Turun, TNI Teratas," CNNIndonesia.
}

that the decline in public trust in the KPK has been revealed by many survey institutions, such as Alvara, Indo Barometer, and Litbang (Research and Development) Kompas. ICW claimed that one of the factors in the decline in public trust in the KPK was due to Law Number 19 Year 2019 which replaced Law Number 30 Year 2002.

The decline in public trust began with the process of ratifying the latest KPK Law which was considered due to a discrepancy with the provisions of the ratification of applicable laws and regulations. The KPK Law which was the House of Representatives' initiative seemed forced considering that the term of office of members of the House of Representatives at that time would expire on September 30, 2019. This means the revision of the KPK Law only had three weeks to be finalized and passed into law. If examined, the revision of the law is too hasty considering it was discussed very quickly. This resulted in strong protests and rejection from various elements of society who did not expect a revision of the KPK Law. This raised the assumption that the revision of the KPK Law does not contain the principle of transparency. In fact, during the process, there had been large demonstrations against the revision of the KPK Law.

Another factor that caused the decline in the level of public trust in the KPK was the influence of the new leaders of the KPK, especially Firli Bahuri who unanimously became the Head of the KPK since 2019. His figure as the candidate of the leader of the KPK at that time had become controversial because there were allegations of ethical violations he committed while he served as Deputy for Prosecution of the KPK. The election of Firli Bahuri had significant impact on the KPK. This can be seen when the Deputy Head of the KPK, Saut Situmorang, chose to resign from his position at the KPK shortly after the House of Representatives chose five new KPK leaders including the Head of the KPK, Firli Bahuri. In addition, Tsani Annafari, the Advisor to the KPK, had previously resigned from his position as an advisor to the KPK. At that time, Tsani Annafari said that he had prepared a draft of his resignation letter since the selection process for the KPK leader candidates. He said he would resign if the person he judged had been proven to have violated ethics was elected as the KPK leader. 
The next factor is that the KPK is considered not to be respected because the KPK is currently not showing its capability by uncovering large-scale corruption cases. Not only the lack of success in uncovering large-scale corruption cases, the KPK is also considered to be incompetent in arresting fugitives suspected of corruption cases. The KPK is completely silent and takes minimal action.

The impact of the latest KPK Law is not only a decline in the level of public trust in the KPK. The latest KPK Law actually strengthens the culture of impunity among the nation's public officials. This can be seen from the lack of follow-up on the recommendations previously given by the KPK to government institutions. One of the reasons for this lack of compliance is the weakening of the KPK's authority in law enforcement. Recommendations to central and regional institutions, such as increasing BPJS Health dues, collecting data on social safety net for handling Covid-19, and implementing the Pre-Employment Card Program have not been fully implemented. In fact, these sectors are very strategic and have an impact on society.

\section{CONCLUSION}

There are several weaknesses in the old KPK Law which caused it to be replaced with the latest KPK Law. Some of the problems that occur have not been able to be properly accommodated in the old KPK Law. Apparently, after the revision of the KPK Law in 2019, the impact of the latest KPK Law has not been seen clearly when viewed from the public's perspective. There has not been a significant positive impact as predicted by those who are aggressively pro against the revision of the KPK Law. There are so many tasks for the KPK in the midst of very high public expectations of this anti-corruption institution.

\section{SUGGESTION}

With the revision of the KPK Law, the latest KPK Law must be implemented optimally. This is to show the existence and capability of the KPK in handling corruption cases again. The KPK must continue to develop and improve its performance with democratic leadership and uphold the value of transparency. By using the latest KPK Law, the KPK must find the best strategy in dealing with problems, both internal and external problems after the ratification of the latest KPK Law.

\section{ACKNOWLEDGMENT}

The researchers would like to express gratitude to Allah SWT and all parties who have supported the researchers in the making of this paper. The researchers hope that this paper is useful.

\section{BIBLIOGRAPHY}

Abdullah, Junaidi. “Tugas Dan Wewenang Lembaga- Lembaga Penanganan Tindak Pidana Korupsi Di Indonesia." Yudisia 5, no. 1 (2014): 102-122. http://journal.stainkudus. ac.id/index.php/Yudisia/article/view/696.

Adji, Indriyanto Seno. Korupsi Kebijakan Aparatur Negara Dan Hukum Pidana. (Jakarta: Diadit Media, 2009): 373

—. KPK Dan Penegakan Hukum. (Jakarta: Diadit Media, 2015): 1

Agustine, O V, E M Sinaga, and R Yulistyaputri. "Politik Hukum Penguatan Kewenangan Komisi Pemberantasan Korupsi Dalam Sistem Ketatanegaraan.” Konstitusi 16, no. 2 (2019): 314-338.

Alkostar, Artidjo. Korupsi Sebagai Extra Ordinary Crime. Training Pengarusutamaan Pendekatan Hak Asasi Manusia Dalam Pemberantasan Korupsi di Indonesia Bagi Hakim Seluruh Indonesia, 2013: 1.

Arman Tjoneng, Christin Septina Basani, Novalita Sidabutar. "Menguji Kewenangan Dewan Pengawas Komisi Pemberantasan Korupsi Dalam Pemberian Izin Penggeledahan Sebagai Tindakan Merintangi Proses Penyidikan (Obstruction of Justice)." Jurnal Esensi Hukum 2, no. 2 (2020): 48-61.

Arrsa, Ria Casmi. "Rekonstruksi Politik Hukum Pemberantasan Korupsi Melalui Strategi Penguatan Penyidik Dan Penuntut Umum Independen KPK." Jurnal Rechts Vinding: Media Pembinaan Hukum Nasional 3, no. 3 (2014): 381.

_. "Urgensi Membentuk KPK Di Daerah." INTEGRITAS Jurnal Anti Korupsi 2, no. 1 (2016): 215-234.

Asep A. Sahid. "Konflik KPK VS POLRI Jilid III: Kontestasi Kuasa Dalam Penegakan Hukum Di Indonesia.” Asy-Syari 'ah 17, no. 2 (2015): 140. 
Asyikin, Nehru dan Adam Setiawan. "Kedudukan KPK Dalam Sistem Ketatanegaraan Pasca Diterbitkannya Revisi Undang-Undang KPK." Justitia Jurnal Hukum Volume 4, no. 1 (2020): 126-147. file:///C:/Users/HP/ Downloads/3736-12588-1-PB.pdf.

Badjuri,Achmad. "Peranan Komisi Pemberantasan Korupsi (KPK) Sebagai Lembaga Anti Korupsi Di Indonesia." Jurnal Bisnis dan Ekonomi (JBE), 18, no. 1 (2011): 84-96.

Dahoklory, Madaskolay Viktoris, and Muh Isra Bil Ali. "Menyoal Urgensi Dan Prosedur Pembentukan Revisi Undang-Undang Komisi Pemberantasan Korupsi." Perspektif 25, no. 2 (2020): 120.

Daya, B. "Memperkuat KPK, Memberantas Korupsi." Lex Librum: Jurnal Ilmu Hukum 5 (2019): 875-886.

Hartanti, Evi. Tindak Pidana Korupsi. 2nd ed. Jakarta: Sinar Grafika, 2012: 1

Hatta, Moh. KPK Dan Sistem Peradilan Pidana. Yogyakarta: Liberty Yogyakarta, $2014: 3$

Indrayana, Denny. Jangan Bunuh KPK. Malang: Intrans Publishing, 2016: 192

Maharani, Tsarina. "Ramai-Ramai Mundur Dari KPK, Ada Apa?" Nasional Kompas. Last modified 2020. Accessed April 3, 2021. https://nasional.kompas.com/ $\mathrm{read} / 2020 / 09 / 30 / 09173581 /$ ramai-ramaimundur-dari-kpk-ada-apa?page $=$ all.

Materay, Korneles. "UU KPK Terbukti Menghambat Kinerja Pemberantasan Korupsi Oleh." Hukum Online. Last modified 2020. Accessed April 3, 2021. https://www.hukumonline.com/berita/ baca/lt5e27d2ad508c5/uu-kpk-terbuktimenghambat-kinerja-pemberantasankorupsi-oleh--korneles-materay?page $=2$.

Mochtar, Zainal Arifin. Lembaga Negara Independen: Dinamika Perkembangan Dan Urgensi Penataannya Kembali PascaAmandemen Konstitusi. Jakarta: Rajawali Pers, 2017: 82

Muttaqin, Labib, and Edy Susanto. "Mengkaji Serangan Balik Koruptor Terhadap KPK Dan Strategi Menghadapinya." Jurnal Integritas 4, no. 1 (2018): 101-144. https:// jurnal.kpk.go.id/index.php/integritas/article/ view/146/45.
Nurdin, Muhammad. Pendidikan Anti Korupsi. Yogyakarta: Ar Ruzz Media, 2014: 7

Setiawan, Adam. "KPK Di Ambang Kehancuran." Kaltim Prokal. Last modified 2019. Accessed March 20, 2021. https://kaltim. prokal.co/read/news/360951-kpk-diambangkehancuran.html.

Sugiarto, Totok. "Peranan KPK Dalam Pemberantasan Tindak Pidana Korupsi Di Indonesia." Jurnal Cakrawala Hukum 18, no. 1 (2013): 188-196.

Telaumbanua, Dalinama. "Restriktif Status Dewan Pengawas KPK." Jurnal Education and development Volume 8, no. 1 (2020): 258-261. http://journal.ipts.ac.id/index.php/ ED/article/view/1545/713.

Wardah, Fathiyah. "Panitia Angket DPR Simpulkan Kinerja KPK Belum Maksimal." VOA Indonesia. Last modified 2018. Accessed March 31, 2021. https://www.voaindonesia. $\mathrm{com/a/panitia-angket-dpr-simpulkan-}$ kinerja-kpk-belum-maksimal-/4254562. html.

Wardhana, Allan Fatchan Gani. "KPK Bukan Eksekutif." PSHK UII. Last modified 2018. Accessed March 28, 2021. https://pshk.uii. ac.id/2018/02/kpk-bukan-eksekutif/.

"Kepercayaan Publik Ke KPK Turun, TNITeratas." CNNIndonesia. Lastmodified 2020.Accessed March 25, 2021. https://www.cnnindonesia. com/nasional/20200224073216-12-477361/ indo-barometer-kepercayaan-publik-ke-kpkturun-tni-teratas.

Maksimal." VOA Indonesia. Last modified 2018. Accessed March 31, 2021. https:// www.voaindonesia.com/a/panitia-angketd pr-simpulkan-kinerja-kpk-bel um maksimal-/4254562.html.

Wardhana, Allan Fatchan Gani. "KPK Bukan Eksekutif." PSHK UII. Last modified 2018. Accessed March 28, 2021. https://pshk.uii. ac.id/2018/02/kpk-bukan-eksekutif/.

"Kepercayaan Publik Ke KPK Turun, TNITeratas." CNNIndonesia. Lastmodified 2020.Accessed March 25, 2021. https://www.cnnindonesia. com/nasional/20200224073216-12-477361/ indo-barometer-kepercayaan-publik-ke-kpkturun-tni-teratas. 